\title{
Complex Formation in a Liquid-Liquid Extraction System Containing Cobalt(II), 4-(2-Pyridylazo)resorcinol, and Nitron
}

\author{
Petya Vassileva Racheva, ${ }^{1}$ Kiril Blazhev Gavazov, ${ }^{2}$ \\ Vanya Dimitrova Lekova, ${ }^{2}$ and Atanas Nikolov Dimitrov ${ }^{2}$ \\ ${ }^{1}$ Department of Chemistry and Biochemistry, Medical University Plovdiv, 15A Vassil Aprilov Boulevard, 4002 Plovdiv, Bulgaria \\ ${ }^{2}$ Department of General and Inorganic Chemistry, University of Plovdiv "Paisii Khilendarski", 24 Tsar Assen Street, \\ 4000 Plovdiv, Bulgaria
}

Correspondence should be addressed to Kiril Blazhev Gavazov; kgavazov@abv.bg

Received 12 December 2012; Revised 23 February 2013; Accepted 24 February 2013

Academic Editor: Concepción López

Copyright (C) 2013 Petya Vassileva Racheva et al. This is an open access article distributed under the Creative Commons Attribution License, which permits unrestricted use, distribution, and reproduction in any medium, provided the original work is properly cited.

Complex formation and liquid-liquid extraction were studied in a system containing cobalt(II), 4-(2-pyridylazo)resorcinol (PAR), 1,4-diphenyl-3-(phenylamino)-1H-1,2,4-triazole (Nitron, Nt), water, and chloroform. The effect of some experimental parameters $(\mathrm{pH}$, shaking time, concentration of PAR, and concentration of $\mathrm{Nt}$ ) was systematically investigated, and the optimum conditions for cobalt extraction as an ion-association complex, $\left(\mathrm{NtH}^{+}\right)\left[\mathrm{Co}^{3+}(\mathrm{PAR})_{2}\right]$, were found. The following key equilibrium constants were calculated: constant of association $(\log \beta=4.77 \pm 0.06)$, constant of distribution $\left(\log K_{\mathrm{D}}=1.34 \pm 0.01\right)$, and constant of extraction $\left(\log K_{\mathrm{ex}}=6.11 \pm 0.07\right)$. Beer's law was obeyed for Co concentrations up to $1.7 \mu \mathrm{g} \mathrm{mL}^{-1}$ with a molar absorptivity of $6.0 \times 10^{4} \mathrm{~L} \mathrm{~mol}^{-1} \mathrm{~cm}^{-1}$ at $\lambda_{\max }=520 \mathrm{~nm}$. Some additional characteristics, such as limit of detection, limit of quantification, and Sandell's sensitivity, were estimated as well.

\section{Introduction}

Cobalt is a transition metal which plays an essential role in industry and all living organisms. Its main applications are in the production of special steels and alloys, permanent magnets, cutting tools, batteries, catalysts, pigments for enamels and glass, and dryers for oil, paints, and varnishes. In biological systems cobalt acts as an active nutrient and an active center of coenzymes called cobalamines. The most important representative of this class of compounds is vitamin B-12: a key substance, which is normally involved in the metabolism of every cell of the human body, especially affecting DNA synthesis and neurologic function [1]. Cobalt deficiency (and hence vitamin B-12 deficiency) can lead to a wide spectrum of hematologic, neuropsychiatric, and cardiovascular disorders. On the other hand, cobalt can be toxic when consumed in excessive quantities $[2,3]$. That is why its content in various samples is monitored, despite the fact that the existing methods for cobalt determination are not enough sensitive or cost effective [4-7].
4-(2-Pyridylazo)resorcinol (PAR) has been proved to be one of the most important reagents for cobalt separation, preconcentration and determination [6-26]. PAR forms with $\mathrm{Co}(\mathrm{II})$ intensively colored anionic chelates, $\left[\mathrm{Co}^{2+}(\mathrm{PAR})_{2}\right]^{2-}$ or $\left[\mathrm{Co}^{3+}(\mathrm{PAR})_{2}\right]^{-}$, which can readily react with bulky organic compounds [20-36] to give ternary complexes with good extraction behavior and analytical potential. In the present paper, we investigated the complex formation in a liquidliquid extraction system containing $\mathrm{Co}(\mathrm{II}), \mathrm{PAR}$, and Nitron (Nt). Nt (Figure 1) is a low-cost and low-toxic analytical reagent that has been commercially available for more than a century; however, some novel aspects of its chemical nature have been recently disclosed [37]. It should be said that extraction systems containing both PAR and Nt have been weakly studied. To the best of our knowledge, the only reported investigations in this field concern vana$\operatorname{dium}(\mathrm{V})$ extraction and spectrophotometric determination [38]. 


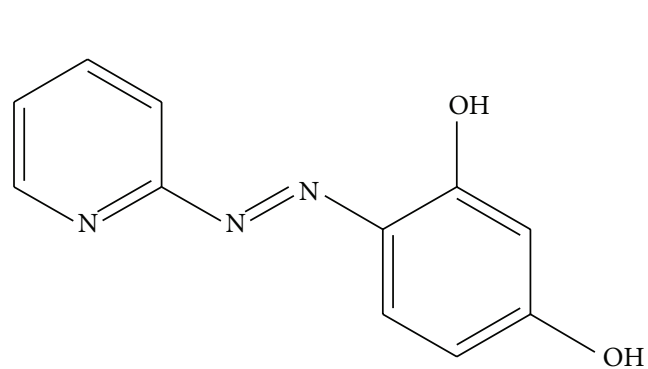

(a)

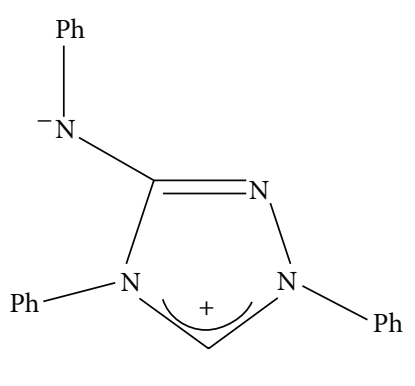

(b)

FIGURE 1: Reagents in the present study, (a) 4-(2-pyridylazo)resorcinol (PAR), (b) 1,4-diphenyl-3-(phenylamino)-1H-1,2,4-triazole (Nitron, $\mathrm{Nt})$.

\section{Experimental}

\subsection{Reagents and Apparatus}

(i) $\mathrm{CoSO}_{4} \cdot 7 \mathrm{H}_{2} \mathrm{O}$ (ReagentPlus, $\geq 99 \%$, Sigma-Aldrich), $1000 \mathrm{mg} \mathrm{L}^{-1}$ stock aqueous solution. Working solutions $\left(C_{\mathrm{Co}}=1.7 \times 10^{-4} \mathrm{~mol} \mathrm{~L}^{-1}\right)$ were prepared by dilution.

(ii) PAR (96\%, Sigma-Aldrich) dissolved in slightly alkalized distilled water, $2 \times 10^{-3} \mathrm{~mol} \mathrm{~L}^{-1}$.

(iii) Nitron ( $\geq 97 \%$, Fluka), $3.5 \times 10^{-4} \mathrm{~mol} \mathrm{~L}^{-1}$ chloroform solution freshly prepared each day.

(iv) Acetate buffer solution, prepared by mixing of $2 \mathrm{~mol} \mathrm{~L}^{-1}$ aqueous solutions of $\mathrm{CH}_{3} \mathrm{COOH}$ and $\mathrm{NH}_{4} \mathrm{OH}$. The resulting $\mathrm{pH}$ was checked by $\mathrm{HI}$ $83140 \mathrm{pH}$ meter (Italy).

(v) Chloroform (additionally distilled).

(vi) Ultrospec 3300 pro UV/visible spectrophotometer (Amersham Biosciences), equipped with $10 \mathrm{~mm}$ pathlength cells.

2.2. Procedure for Establishing the Optimum Operating Conditions. Aliquots of $\mathrm{Co}(\mathrm{II})$ solution, PAR solution (up to $1.4 \mathrm{~mL}$ ), and buffer solution $(5 \mathrm{~mL}$; $\mathrm{pH}$ ranging from 3.0 to 6.2) were introduced into $250 \mathrm{~mL}$ separatory funnels. The resulting solutions were diluted with distilled water to a total volume of $10 \mathrm{~mL}$. Appropriate amounts of $\mathrm{Nt}$ solution and chloroform were added in a total volume of $10 \mathrm{~mL}$. Then the funnels were shaken for a fixed time (up to $5.0 \mathrm{~min}$ ). A portion of the organic extract was filtered through a filter paper (to prevent the opportunity of water droplets transfer) into a cell and the absorbance read against a blank. The blank extraction was performed at the same manner, but in the absence of Co.

2.3. Procedure for Determination of the Distribution Constant. The distribution constant $K_{D}$ was found from the ratio $K_{D}=A_{1} /\left(A_{2}-A_{1}\right)$, where $A_{1}$ and $A_{2}$ are the absorbances (measured against blanks) obtained after a single and double extraction, respectively. The single extraction and the first stage of the double extraction were performed
TABLE 1: Optimum conditions and analytical characteristics of the $\mathrm{Co}(\mathrm{II})$-PAR-Nt-water-chloroform system.

\begin{tabular}{lc}
\hline Optimum conditions & Analytical characteristics \\
\hline Wavelength: $520 \mathrm{~nm}$ & Molar absorptivity: \\
& $\varepsilon=6.0 \times 10^{4} \mathrm{~L} \mathrm{~mol}^{-1} \mathrm{~cm}^{-1}$ \\
pH: 5.3 (acetate buffer) & Beer's law range: \\
$C_{\mathrm{PAR}}: 1.0 \times 10^{-4} \mathrm{~mol} \mathrm{~L}^{-1}$ & up to $1.7 \mu \mathrm{g} \mathrm{mL}^{-1}$ \\
$C_{\mathrm{Nt}}: 3.0 \times 10^{-4} \mathrm{~mol} \mathrm{~L}^{-1}$ & Limit of detection: $0.06 \mu \mathrm{g} \mathrm{mL}$ \\
Shaking time: $15-20 \mathrm{sec}$ & Limit of quantification: \\
\hline
\end{tabular}

under the optimum extraction-spectrophotometric conditions (Table 1). The organic layers were transferred into $25 \mathrm{~mL}$ calibrated flasks and the flask for the single extraction was brought to volume with $\mathrm{Nt}$ solution. The second stage of the double extraction was performed by adding another $10 \mathrm{~mL}$ portion of the $\mathrm{Nt}$ solution to the aqueous phase, which remained after the first stage. After shaking, the organic layer was added to the one obtained after the first stage and the volume was brought to the mark with $\mathrm{Nt}$ solution. Before the spectrophotometric measurement, the calibrated flasks were shaken for homogenization.

\section{Results and Discussion}

3.1. Absorption Spectra. Spectra of the extracted ternary CoPAR-Nt complex and the blank are shown in Figure 2. A maximum is recorded at $520 \mathrm{~nm}$, where the blank absorbs insignificantly. It is shifted to $10 \mathrm{~nm}$ as compared to the maximum of the binary Co-PAR chelate existing in aqueous medium (in the $\mathrm{pH}$ interval from 3.5 to 10): $510 \mathrm{~nm}$ [9, 27, 29, $31,39]$. The observed bathochromic effect is small and gives us grounds to suggest the formation of a ternary compound of the ion-association type.

3.2. Effect of $p H$. Results showed that the optimal $\mathrm{pH}$ for the extraction of Co with PAR and Nt is 5.2-5.4 (Figure 3). A buffer solution with a concentration of $2 \mathrm{~mol} \mathrm{~L}^{-1}$ was applied to control $\mathrm{pH}$. The use of $0.25-5 \mathrm{~mL}$ of the buffer solution per $10 \mathrm{~mL}$ (final aqueous solution) was found to give a constant 


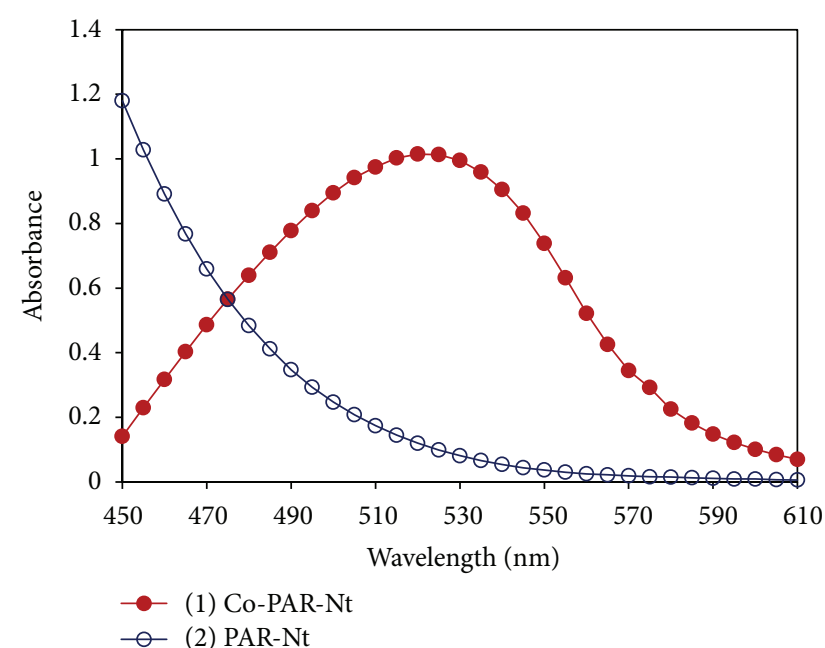

Figure 2: Absorption spectra of the ternary Co-PAR-Nt complex and the blank (PAR-Nt) in chloroform. $C_{\mathrm{Co}}=1.7 \times 10^{-5} \mathrm{~mol} \mathrm{~L}^{-1}$, $C_{\mathrm{PAR}}=1.4 \times 10^{-4} \mathrm{~mol} \mathrm{~L}^{-1}, C_{\mathrm{Nt}}=3.5 \times 10^{-4} \mathrm{~mol} \mathrm{~L}^{-1}$, and $\mathrm{pH}=5.3$, $l=1 \mathrm{~cm}$

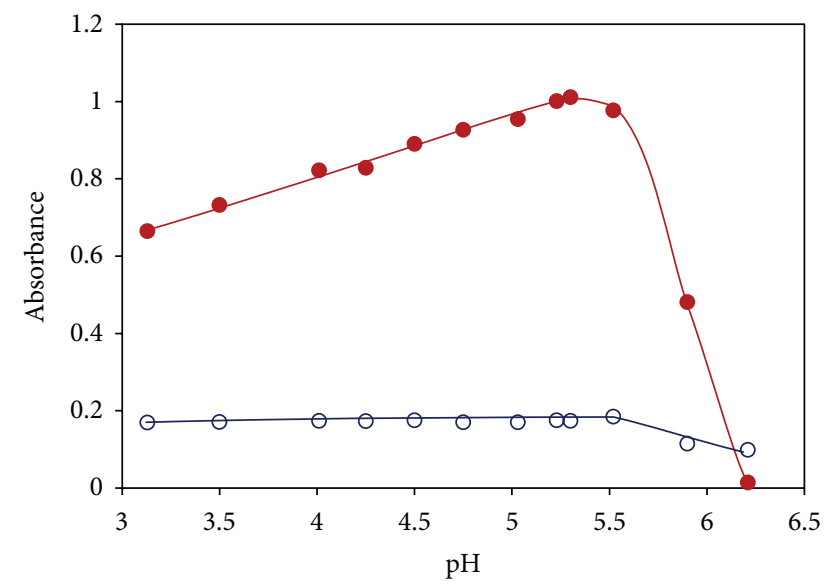

- (1) Co-PAR-Nt

o (2) PAR-Nt

FIgURE 3: Absorbance of Co-PAR-Nt extracts against blank (line 1) and blank against chloroform (line 2) versus $\mathrm{pH}$ of the aqueous phase plots. $C_{\mathrm{Co}}=1.7 \times 10^{-5} \mathrm{~mol} \mathrm{~L}^{-1}, C_{\mathrm{PAR}}=1.4 \times 10^{-4} \mathrm{~mol} \mathrm{~L}^{-1}$, $C_{\mathrm{Nt}}=3.5 \times 10^{-4} \mathrm{~mol} \mathrm{~L}^{-1}, \lambda=520 \mathrm{~nm}$, and $l=1 \mathrm{~cm}$.

absorbance. All further experiments were carried out with $5 \mathrm{~mL}$ buffer solution with $\mathrm{pH}=5.2-5.3$.

3.3. Effect of Reagents' Concentrations. The effect of PAR and Nt concentrations on the absorbance is shown in Figure 4. For up to $1.7 \mu \mathrm{g} \mathrm{mL}^{-1}$ of $\mathrm{Co}$, the use of about $0.5 \mathrm{~mL}$ of $2.0 \times$ $10^{-3} \mathrm{~mol} \mathrm{~L}^{-1}$ PAR and $8.5 \mathrm{~mL}$ of $3.5 \times 10^{-4} \mathrm{~mol} \mathrm{~L}^{-1} \mathrm{Nt}$ was found to be sufficient for a complete cobalt extraction.

3.4. Effect of Shaking Time. The extraction equilibrium is reached for a short shaking time (about 5 seconds). It was found that a shaking time longer than 1 min can bring about to a slight decrease (5-6\%) of the absorbance values. To

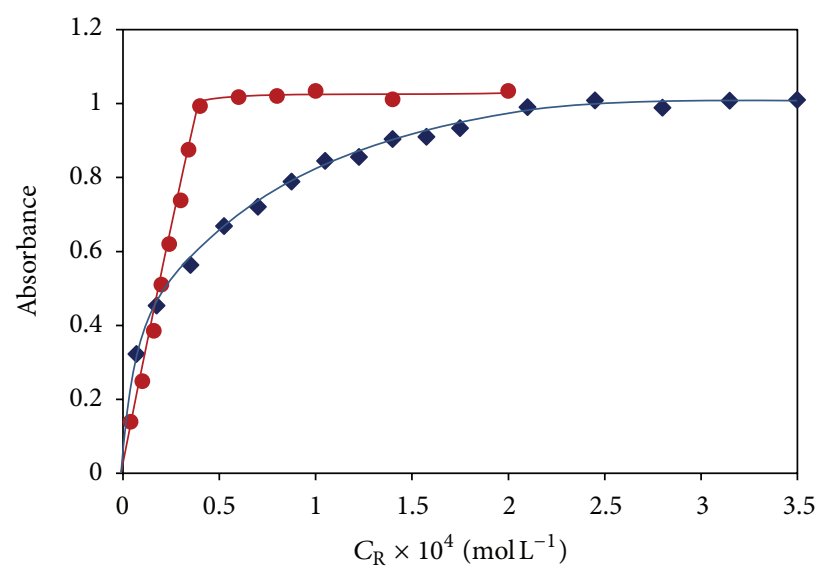

(1) $\mathrm{R}=\mathrm{PAR}$

- (2) $\mathrm{R}=\mathrm{Nt}$

FIgURE 4: Absorbance of the extracted ternary complex versus concentration of the PAR (curve 1) and Nt (curve 2) plots. (1) $C_{\mathrm{Co}}=$ $1.7 \times 10^{-5} \mathrm{~mol} \mathrm{~L}^{-1}, C_{\mathrm{Nt}}=3.5 \times 10^{-4} \mathrm{~mol} \mathrm{~L}^{-1}, \lambda=520 \mathrm{~nm}$, and $l=1 \mathrm{~cm}$. (2) $C_{\mathrm{Co}}=1.7 \times 10^{-5} \mathrm{~mol} \mathrm{~L}^{-1}, C_{\mathrm{PAR}}=1.4 \times 10^{-4} \mathrm{~mol} \mathrm{~L}^{-1}$, $\lambda=520 \mathrm{~nm}$, and $l=1 \mathrm{~cm}$.

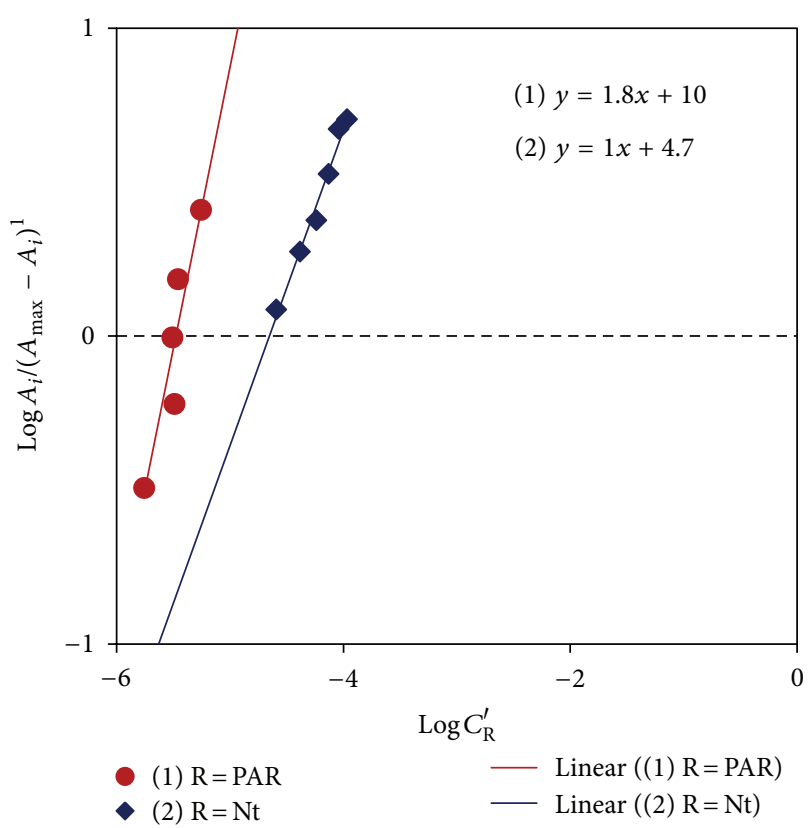

Figure 5: Determination of the PAR-to-Co (1) and Nt-to-Co (2) molar ratios by the mobile equilibrium method. (1) $C_{\mathrm{Co}}=1.7 \times$ $10^{-5} \mathrm{~mol} \mathrm{~L}^{-1}, C_{\mathrm{Nt}}=3.5 \times 10^{-4} \mathrm{~mol} \mathrm{~L}^{-1}, \mathrm{pH}=5.3, \lambda=520 \mathrm{~nm}$, and $l=1 \mathrm{~cm}$. (2) $C_{\mathrm{Co}}=1.7 \times 10^{-5} \mathrm{~mol} \mathrm{~L}^{-1}, C_{\mathrm{PAR}}=1.0 \times 10^{-4} \mathrm{~mol} \mathrm{~L}^{-1}$, $\mathrm{pH}=5.3, \lambda=520 \mathrm{~nm}$, and $l=1 \mathrm{~cm}$.

avoid this disadvantage and to guarantee complete transfer of the complex into organic phase, even under nonoptimum conditions, the authors extracted in their experiments for 1520 seconds.

3.5. Composition of the Complex and Suggested Formula. The molar PAR-to-Co(II) and Nt-to-Co(II) ratios were determined by the mobile equilibrium method [40] (Figure 5), molar ratio method [43] (see Figure 4), and the 
TABLE 2: Calculated values of $\log \beta, \log K_{D}, \log K_{\text {ex }}$, and $\mathrm{R} \%$.

\begin{tabular}{lcr}
\hline Equilibrium & Equilibrium constant & Value \\
\hline & & $\log \beta=4.7 \pm 0.3^{\mathrm{a}}$ \\
$(1)$ & $\beta=\left[(\mathrm{NtH})\left[\mathrm{Co}(\mathrm{PAR})_{2}\right]\right] /\left[\mathrm{NtH}^{+}\right] \times\left[\left[\mathrm{Co}(\mathrm{PAR})_{2}\right]^{-}\right]$ & $\log \beta=4.77 \pm 0.06^{\mathrm{b}}$ \\
& $K_{\mathrm{D}}=\left[(\mathrm{NtH})\left[\mathrm{Cog}(\mathrm{PAR})_{2}\right]\right]_{\mathrm{org} /\left[(\mathrm{NtH})\left[\mathrm{Co}(\mathrm{PAR})_{2}\right]\right]_{\mathrm{aq}}}$ & $\log K_{D}=1.34 \pm 0.1^{\mathrm{c}}$ \\
$(2)$ & $K_{\mathrm{ex}}=\left[(\mathrm{NtH})\left[\mathrm{Co}(\mathrm{PAR})_{2}\right]\right]_{\mathrm{org}}\left[\mathrm{NtH}^{+}\right]_{\mathrm{aq}} \times\left[\left[\mathrm{Co}(\mathrm{PAR})_{2}\right]_{\mathrm{aq}}\right.$ & $\log K_{\mathrm{ex}}=6.11 \pm 0.07^{\mathrm{d}}$ \\
\hline$(3)$ &
\end{tabular}

Calculated by the mobile equilibrium method [40].

${ }^{\mathrm{b}}$ Calculated by the Holme-Langmihr method [41].

${ }^{c}$ Calculated by the Harvey-Manning method [42].

${ }^{\mathrm{d}}$ Calculated by the formula $K_{\mathrm{ex}}=K_{D} \times \beta$, where $\beta$ is determined by the Holme-Langmihr method.

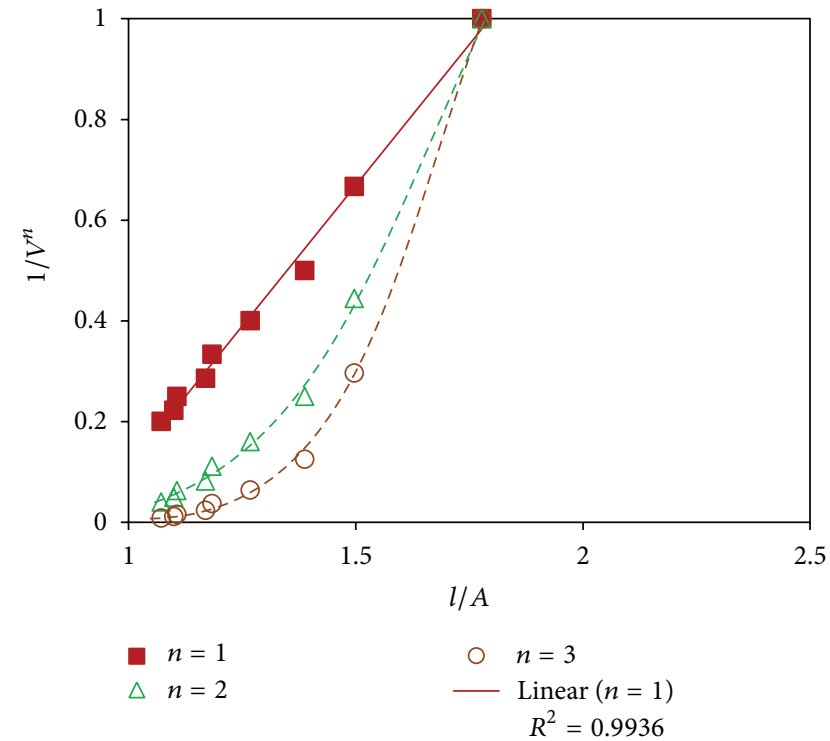

FIGURE 6: Determination of the Nt-to-Co molar ratio by the method of Asmus. $C_{\mathrm{Co}}=1.7 \times 10^{-5} \mathrm{~mol} \mathrm{~L}^{-1}, C_{\mathrm{PAR}}=1.0 \times 10^{-4} \mathrm{~mol} \mathrm{~L}^{-1}$, $\mathrm{pH}=5.3, \lambda=520 \mathrm{~nm}$, and $l=1 \mathrm{~cm}$.

method of Asmus [44] (Figure 6). The results showed that the ternary complex has a composition of $1: 2: 1$ (Co: PAR: Nt). Having in mind the obtained molar ratios and several reports, which convincingly demonstrate that the labile Co(II)-PAR complex can be easily oxidized to an inert Co(III)-PAR complex, $\left[\mathrm{Co}^{3+}(\mathrm{PAR})_{2}\right]^{-}$, by the atmospheric oxygen $[13,26,29,32,33,36,45]$, we suggest the following formula of the extracted ternary species: $(\mathrm{NtH})^{+}\left[\mathrm{Co}^{3+}(\mathrm{PAR})_{2}\right]^{-}$. In this formula, PAR is in deprotonated form $\left(\mathrm{PAR}^{2-}\right)$, while $\mathrm{Nt}$ is in protonated form $\left(\mathrm{NtH}^{+}\right)$. The mentioned formula and the known properties of PAR [45-47] and Nt [48] fit well to the observed $\mathrm{pH}$ curve of the ternary complex presented in Figure 3: (1) at $\mathrm{pH}$ values lower than $\mathrm{pH}_{\text {opt }} \mathrm{PAR}$ is hardly possible to be in its $\mathrm{PAR}^{2-}$ form; (2) at $\mathrm{pH}$ values higher than $\mathrm{pH}_{\text {opt }} \mathrm{Nt}$ is hardly possible to be in its $\mathrm{NtH}^{+}$form. The right part of the $\mathrm{pH}$ curve has a steeper slope, because the limitation 2 is more strictly.

3.6. Equilibrium Constants and Recovery. Several equilibrium processes should be taken into account for the system of $\left[\mathrm{Co}(\mathrm{PAR})_{2}\right]^{-}, \mathrm{NtH}^{+}$, water, and chloroform. (i) Formation of ion-association complex in the aqueous phase:

$$
\mathrm{NtH}^{+}+\left[\mathrm{Co}(\mathrm{PAR})_{2}\right]^{-} \longleftrightarrow(\mathrm{NtH})\left[\mathrm{Co}(\mathrm{PAR})_{2}\right]
$$

(ii) Distribution of the complex between the aqueous and the organic phase:

$$
(\mathrm{NtH})\left[\mathrm{Co}(\mathrm{PAR})_{2}\right]_{\mathrm{aq}} \longleftrightarrow(\mathrm{NtH})\left[\mathrm{Co}(\mathrm{PAR})_{2}\right]_{\mathrm{org}}
$$

(iii) Extraction from water into chloroform:

$$
\left[\mathrm{Co}(\mathrm{PAR})_{2}\right]_{\mathrm{aq}}^{-}+\mathrm{NtH}_{\mathrm{aq}}^{+} \longleftrightarrow(\mathrm{NtH})\left[\mathrm{Co}(\mathrm{PAR})_{2}\right]_{\mathrm{org}}
$$

The equilibrium constants describing these equations and the obtained values are shown in Table 2. The association constant $\beta$ was determined by several independent methods: Holme-Langmihr method [41], Harvey-Manning method [42], and mobile equilibrium method [40] (Figure 5, straight line 2). The distribution constant $K_{D}$ was calculated from the absorption values obtained after single and double extraction as described above. The extraction constant $K_{\text {ex }}$ was calculated by the formula $K_{\mathrm{ex}}=K_{D} \times \beta$. The recovery factor $R$ was estimated by the dependence $R \%=100 K_{D} /\left(K_{D}+\right.$ 1) and the following value was obtained $R=95.7 \%$. All experiments were performed at room temperature of $\sim 22^{\circ} \mathrm{C}$ and the calculations were carried out at a probability of $95 \%$.

3.7. Beer's Law, Molar Absorptivity, and other Analytical Characteristics. The range of adherence to Beer's law was studied at the optimum conditions (Table 1). The linearity is observed up to $1.7 \mu \mathrm{g} \mathrm{mL}^{-1}$ of Co with a correlation coefficient of 0.9995 . The obtained straight line equation is $Y=0.973 \mathrm{X}+0.014$. The molar absorptivity was calculated to be $6.0 \times 10^{4} \mathrm{~L} \mathrm{~mol}^{-1} \mathrm{~cm}^{-1}$. This value could compete successfully with the ones obtained for similar PAR-containing complexes (Table 3). The limit of detection (LOD) and limit of quantification (LOQ) were estimated at 3 times and 10 times standard deviation of the intercept divided by the slope. Sandell's sensitivity was calculated as well. The values of the above-mentioned characteristics are included in Table 1.

\section{Conclusions}

Cobalt(II) forms well chloroform-extractable ternary complex with 4-(2-pyridylazo)resorcinol and Nitron. The complex could be regarded as an ion associate between an 
TABLE 3: Spectral characteristics of some extracted in organic solvents Co-PAR complexes* .

\begin{tabular}{lcccc}
\hline Additional reagent(s) & Organic solvent & $\begin{array}{c}\text { Molar absorptivity, } \\
\mathrm{L} \mathrm{mol}^{-1} \mathrm{~cm}^{-1}\end{array}$ & $\lambda_{\max }, \mathrm{nm}$ & Ref. \\
\hline Xylomethazoline hydrochloride & Chloroform & $4.2 \times 10^{4}$ & 535 & {$[24]$} \\
Diphenylguanidine & Chloroform & $5.0 \times 10^{4}$ & $520-530$ & {$[27]$} \\
Triphenyltetrazolium chloride & Chloroform & $5.0 \times 10^{4}$ & 515 & {$[36]$} \\
Iodonitrotetrazolium chloride & Chloroform & $5.2 \times 10^{4}$ & 515 & {$[36]$} \\
Zephiramine & Chloroform & $5.8 \times 10^{4}$ & 520 & {$[28]$} \\
Tetradecyl-dimethylbenzyl-ammonium chloride + EDTA & Chloroform & $5.9 \times 10^{4}$ & 520 & {$[35]$} \\
Dicyclohexyl-18-crown-6 & 1,2-dichloroethane & $6.0 \times 10^{4}$ & 515 & {$[26]$} \\
Tetraphenylarsonium chloride & Chloroform & $(6.0-6.4) \times 10^{4}$ & 520 & {$[29]$} \\
Tetraphenylphosphonium chloride & Chloroform & $(6.0-6.4) \times 10^{4}$ & 520 & {$[29]$} \\
Nitron & Chloroform & $6.0 \times 10^{4}$ & 520 & This work \\
\hline
\end{tabular}

${ }^{*}$ The molar absorptivity of the binary cobalt-PAR complex in aqueous medium is $\varepsilon_{510}=5.6 \times 10^{4} \mathrm{~L} \mathrm{~mol}^{-1} \mathrm{~cm}^{-1}[39]$.

intensively colored anion, $\left[\mathrm{Co}(\mathrm{PAR})_{2}\right]^{-}$, in which cobalt is in +3 oxidation state, and a bulky hydrophobic cation (protonated Nitron, $\mathrm{NtH}^{+}$). The following equilibrium constants and analytical characteristics were determined: constant of extraction, constant of association, constant of distribution, recovery factor, molar absorptivity, Sandell's sensitivity, limit of detection, and limit of quantification. The obtained values show that the studied extraction system in the present work could compete successfully with many similar systems used for cobalt determination.

\section{Acknowledgment}

The authors would like to thank the Research Fund of the Plovdiv University for its long-time support.

\section{References}

[1] R. C. Oh and D. L. Brown, "Vitamin B12 deficiency," American Family Physician, vol. 67, no. 5, pp. 979-986, 2003.

[2] B. B. Tewari, "Complex formation of some divalent metal ions with oxygen donor ligands," Revista Boliviana de Química, vol. 26, no. 1, pp. 30-36, 2009.

[3] D. G. Barceloux and D. Barceloux, "Cobalt," Clinical Toxicology, vol. 37, no. 2, pp. 201-216, 1999.

[4] R. A. Meyers, Ed., Encyclopedia of Analytical Chemistry: Applications, Theory, and Instrumentation, Wiley, Chichester, UK, 2000.

[5] M. Jakubowski and M. Trzcinka-Ochocka, "Biological monitoring of exposure: trends and key developments," Journal of Occupational Health, vol. 47, no. 1, pp. 22-48, 2005.

[6] A. Tsuyoshi, H. Hoshino, and T. Yotsuyanagi, "Retention selectivity between 4-(2-pyridylazo)resorcinol and its cobalt chelate in the solid phase extraction systems and its application to the on-line preconcentration for reversed phase HPLC," Chemistry Letters, vol. 30, no. 4, pp. 302-303, 2001.

[7] R. E. Taljaard and J. F. V. Staden, "Simultaneous determination of cobalt(II) and $\mathrm{Ni}$ (II) in water and soil samples with sequential injection analysis," Analytica Chimica Acta, vol. 366, no. 1-3, pp. 177-186, 1998.
[8] A. Hol, U. Divrikli, and L. Elci, "Determination of cobalt, nickel and iron at trace level in natural water samples by in-column chelation-reversed phase high-performance liquid chromatography," Environmental Monitoring and Assessment, vol. 184, no. 6, pp. 3469-3479, 2012.

[9] V. M. Ivanov, N. I. Ershova, V. N. Figurovskaya, and A. V. Ivanov, "Optical and chromaticity characteristics of cobalt and palladium 4-(2-pyridylazo)resorcinates," Journal of Analytical Chemistry, vol. 56, no. 2, pp. 143-148, 2001.

[10] G. Ram, R. S. Chauhan, A. K. Goswami, and D. N. Purohit, "Review of spectrophotometric methods for determination of cobalt(II)," Reviews in Analytical Chemistry, vol. 22, no. 4, pp. 255-317, 2003.

[11] H. Ciftci, "Solid phase extraction method for the determination of cobalt in water samples on duolite XAD-761 resin using 4-(2Pyridylazo) resorcinol by FAAS," Current Analytical Chemistry, vol. 6, no. 2, pp. 154-160, 2010.

[12] S. Tokalioğlu and S. Kartal, "Preconcentration of iron(III), lead(II), cobalt(II) and chromium(III) on amberlite XAD1180 resin loaded with 4-(2-pyridylazo)-resorcinol (PAR) and their determination by FAAS," Bulletin of the Korean Chemical Society, vol. 27, no. 9, pp. 1293-1296, 2006.

[13] V. Cucinotta, R. Caruso, A. Giuffrida, M. Messina, G. Maccarrone, and A. Torrisi, "Separation and quantitation of metal ions by 4-(2-pyridylazo)resorcinol complexation in capillary electrophoresis-electrospray ionisation mass spectrometry," Journal of Chromatography A, vol. 1179, no. 1, pp. 17-23, 2008.

[14] Z. T. Jiang, J. C. Yu, and H. Y. Liu, "Simultaneous determination of cobalt, copper and zinc by energy dispersive X-ray fluorescence spectrometry after preconcentration on PAR-loaded ionexchange resin," Analytical Sciences, vol. 21, no. 7, pp. 851-854, 2005.

[15] C. C. Nascentes and M. A. Z. Arruda, "Cloud point formation based on mixed micelles in the presence of electrolytes for cobalt extraction and preconcentration," Talanta, vol. 61, no. 6, pp. 759-768, 2003.

[16] I. V. Vyshcherevich and I. E. Kalinichenko, "Photometric determination in drinking water of cobalt and nickel with 4-(2-pyridylazo)-resorcinol," Journal of Water Chemistry and Technology, vol. 32, no. 1, pp. 33-38, 2010.

[17] M. Ince, G. Kaya, and M. Yaman, "Solid phase extraction and preconcentration of cobalt in mineral waters with PAR-loaded 
Amberlite XAD-7 and flame atomic absorption spectrometry," Environmental Chemistry Letters, vol. 8, no. 3, pp. 283-288, 2010.

[18] L. L. Kolomiets, L. A. Pilipenko, I. M. Zhmud', and I. P. Panfilova, "Application of derivative spectrophotometry to the selective determination of nickel, cobalt, copper, and iron(III) with 4-(2-pyridylazo)resorcinol in binary mixtures," Zhurnal Analiticheskoi Khimii, vol. 54, no. 1, pp. 34-36, 1999.

[19] H. Ciftc1, A. Olcucu, A. Ozkaya, and T. C1ftc1, "Optimization of analytical parameters for determination of iron, nickel and cobalt in plants with RP-HPLC," Asian Journal of Chemistry, vol. 21, no. 4, pp. 2643-2652, 2009.

[20] C. E. Säbel, J. L. Shepherd, and S. Siemann, "A direct spectrophotometric method for the simultaneous determination of zinc and cobalt in metalloproteins using 4-(2pyridylazo)resorcinol," Analytical Biochemistry, vol. 391, no. 1, pp. 74-76, 2009.

[21] B. F. Liu, L. B. Liu, and J. K. Cheng, "Analysis of metal complexes in the presence of mixed ion pairing additives in capillary electrophoresis," Journal of Chromatography A, vol. 848, no. 12, pp. 473-484, 1999.

[22] K. Sato and T. Goto, "Determination of nickel(II) and cobalt(II) in an aqueous solution using 4-(2-Pyridylazo)-resorcinol/ Capriquat-loaded silica gel," Bunseki Kagaku, vol. 47, no. 10, pp. 735-738, 1998.

[23] H. R. Pouretedal, P. Sononi, M. H. Keshavarz, and A. Semnani, "Simultaneous determination of cobalt and iron using firstderivative spectrophotometric and h-point standard addition methods in micellar media," Chemistry, vol. 18, no. 3, pp. 2235, 2009.

[24] S. N. Bhadani, M. Tewari, A. Agrawal, and C. Sekhar, "Extractive-photometric determination of cobalt(II) in steels using 4-(2-pyridylazo)resorcinol and xylometazoline hydrochloride," Journal of the Indian Chemical Society, vol. 75, no. 3, pp. 176-177, 1998.

[25] P. Berton and R. G. Wuilloud, "An online ionic liquidbased microextraction system coupled to electrothermal atomic absorption spectrometry for cobalt determination in environmental samples and pharmaceutical formulations," Analytical Methods, vol. 3, no. 3, pp. 664-672, 2011.

[26] A. G. Gaikwad, H. Noguchi, and M. Yoshio, "Solvent extraction studies of metal-4-(2-pyridyl-azo)-resorcinol complexes with potassium-dicyclohexyl-18-crown-6 complex," Analytical Letters, vol. 24, no. 9, pp. 1625-1641, 1991.

[27] S. G. Mamuliya, I. V. Pyatnitskii, L. L. Kolomiets, and K. I. Grigalashvili, "Solvent extraction of complexes of cobalt, nickel, copper, zinc and cadmium with 4-(2-pyridylazo)-resorcinol and diphenylguanidine," Zhurnal Analiticheskoi Khimii, vol. 35, no. 7, pp. 1306-1309, 1980 (Russian).

[28] R. Yamashita, T. Yotsuyanagi, and K. Aomura, "The extractionspectrophotometric determination of traces of iron and cobalt with 4-(2-pyridylazo)-resorcinol," The Japan Society for Analytical Chemistry, vol. 20, pp. 1282-1288, 1971.

[29] M. Široki, L. Marić, Z. Štefanac, and M. J. Herak, "Characterization of complexes involved in the spectrophotometric determination of cobalt with 4-(2-pyridylazo)resorcinol," Analytica Chimica Acta, vol. 75, no. 1, pp. 101-109, 1975.

[30] J. Dolezal and L. Sommer, "Reverse-phase high performance liquid chromatography of metal chelates of 4-(2pyridylazo)resorcinol and 4-(2-thiazolylazo)resorcinol. Simultaneous determination of low concentrations of $\mathrm{Co}, \mathrm{Ni}$ and $\mathrm{Fe}$," Collection of Czechoslovak Chemical Communications, vol. 59, pp. 2209-2226, 1994.
[31] N. T. Sizonenko and L. V. Gudzenko, "Determination of additions of cobalt in single crystals of cesium iodine, activated by thallium," Zavodskaya Laboratoriya, vol. 51, no. 2, pp. 109-111, 1985 (Russian).

[32] T. Okutani, A. Sakuragawa, and M. Murakami, "Determination of iron, cobalt ad nickel by reverse phase high performance liquid chromatography following ion pair extraction of metal 4-(2-pyridylazo)resorcinol complexes," Analytical Sciences, vol. 7, no. 1, pp. 109-112, 1991.

[33] J. B. Noffsinger and N. D. Danielson, "Retention characteristics of $\mathrm{Co}^{+3}, \mathrm{Fe}^{+3}$, and $\mathrm{Cu}^{+2}$ 4-(2-Pyridylazo)resorcinol (PAR) complexes on C-18 and amino silica packings," Journal of Liquid Chromatography, vol. 9, no. 10, pp. 2165-2183, 1986.

[34] H. Okochi, "Spectrophotometric determination of microamounts of cobalt in iron and steel by solvent extraction of cobalt-4-(2-pyridylazo) resorcinol complex with quaternary ammonium chloride," Bunseki Kagaku, vol. 21, no. 1, pp. 51-56, 1972 (Japanese).

[35] T. Yotsuyanagi, R. Yamashita, and K. Aomura, "Spectrophotometric determination of traces of metals by solvent extraction with 4-(2-pyridylazo)-resorcin-quaternary ammonium saltpolyaminocarboxylic acid system," The Japan Society For Analytical Chemistry, vol. 19, no. 7, pp. 981-982, 1970 (Japanese).

[36] V. V. Divarova, K. B. Gavazov, V. D. Lekova, and A. N. Dimitrov, "Spectrophotometric investigations on liquid-liquid extraction systems containing cobalt, 4-(2-pyridylazo)-resorcinol and tetrazolium salts," Chemija. In press.

[37] C. Farber, M. Leibold, C. Bruhn, M. Maurer, and U. Siemeling, "Nitron: a stable N-heterocyclic carbene that has been commercially available for more than a century," Chemical Communications, vol. 48, no. 2, pp. 227-229, 2012.

[38] R. M. Pogranichnaya, B. E. Reznik, V. V. Nerubashchenko, A. G. Zezyanova, and A. V. Tsevina, "Solvent extraction of mixedligand complexes of vanadium with 4-(2-pyridylazo) resorcinol and nitron," Zhurnal Analiticheskoi Khimii, vol. 30, p. 180, 1975 (Russian).

[39] A. I. Busev and V. M. Ivanov, "1-(2-Pyridylazo)-resorcinol as a reagent for the photometric determination of cobalt," Zhurnal Analiticheskoi Khimii, vol. 18, no. 2, pp. 208-215, 1963 (Russian).

[40] Z. Zhiming, M. Dongsen, and Y. Cunxiao, "Mobile equilibrium method for determining composition and stability constant of coordination compounds of the form MmRn," Journal of Rare Earths, vol. 15, no. 3, pp. 218-219, 1997.

[41] A. Holme and F. J. Langmyhr, "A modified and a new straightline method for determining the composition of weak complexes of the form AmBn," Analytica Chimica Acta, vol. 36, pp. 383-391, 1966.

[42] A. E. Harvey and D. L. Manning, "Spectrophotometric methods of establishing empirical formulas of colored complexes in solution," Journal of the American Chemical Society, vol. 72, no. 10, pp. 4488-4493, 1950.

[43] J. H. Yoe and A. L. Jones, "Colorimetric determination of iron with disodium-1,2-dihydroxybenzene-3,5-disulfonate," Industrial and Engineering Chemistry, vol. 16, no. 2, pp. 111-115, 1944.

[44] E. Asmus, "Eine neue methode zur ermittlung der zusammensetzung schwacher komplexe," Fresenius' Zeitschrift für Analytische Chemie, vol. 178, no. 2, pp. 104-116, 1960 (German).

[45] A. Corsini, Q. Fernando, and H. Freiser, "The effect of metal ion chelation on the acid dissociation of the ligand 4-(2pyridylazo)-resorcinol," Inorganic Chemistry, vol. 2, no. 1, pp. 224-226, 1963. 
[46] F. I. Lobanov, G. K. Nurtaeva, and E. E. Ergozhin, Extraction of Metal Complexes With Hydroxyazo Compounds of Pyridine, Alma-Ata: Nauka, 1983.

[47] L. Marić and M. Široki, "Extraction of 4-(2-pyridylazo) resorcinol and 4-(2-thiazolylazo) resorcinol with chloroform and tetraphenylarsonium and phosphonium chlorides," Analytica Chimica Acta, vol. 318, no. 3, pp. 345-355, 1996.

[48] A. S. Babenko, V. N. Tolmachev, and A. N. Dzizin, "Investigation of sulforic acid salts of nitron," Ukrainskii Khimicheskii Zhurnal, vol. 29, no. 7, pp. 702-708, 1963 (Russian). 

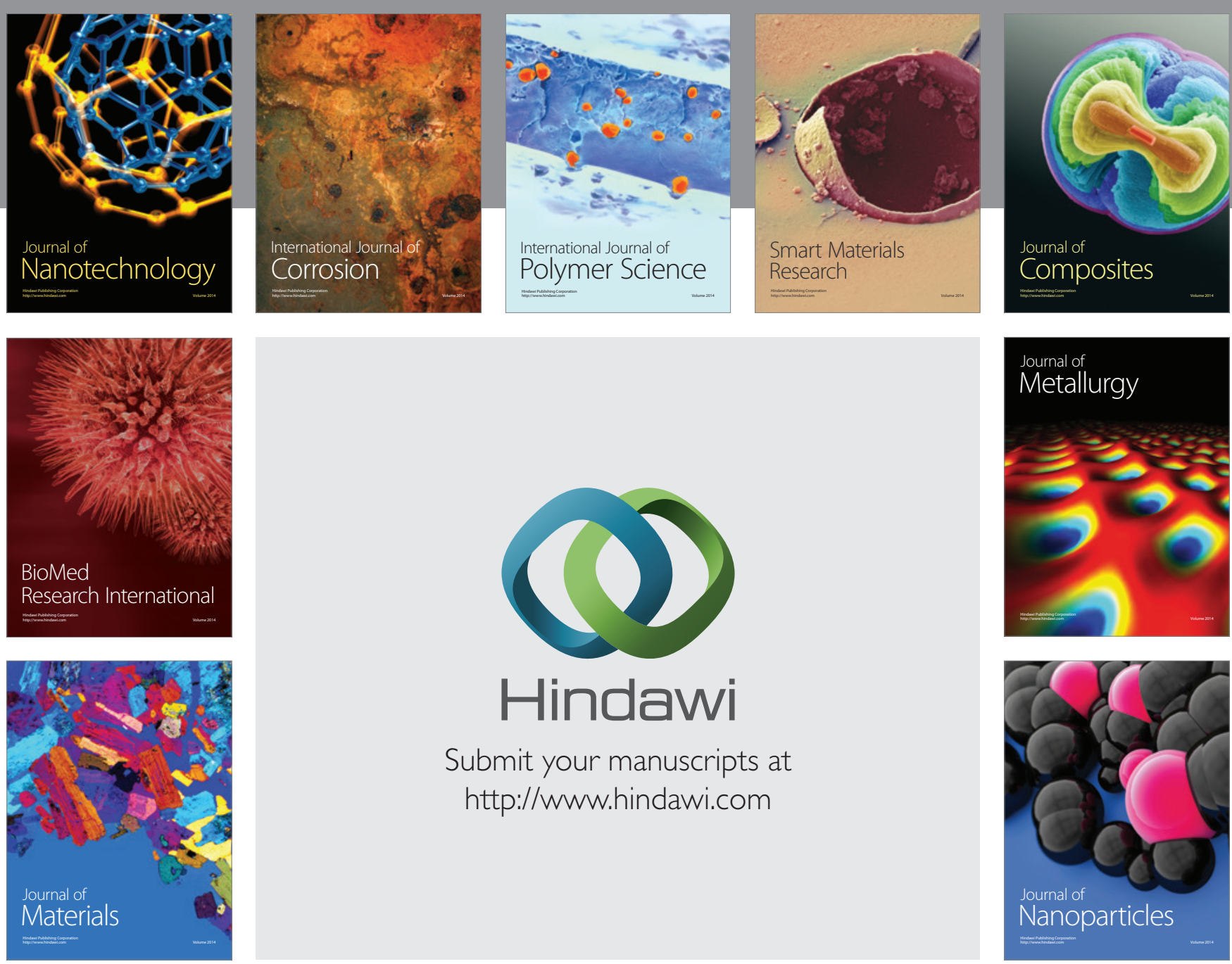

Submit your manuscripts at http://www.hindawi.com
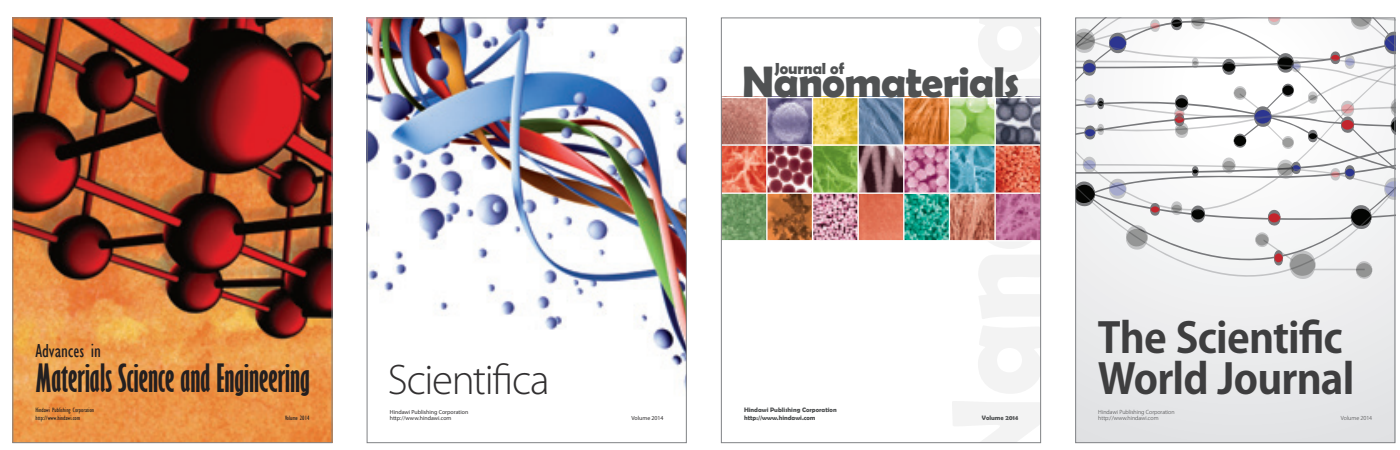

\section{The Scientific World Journal}
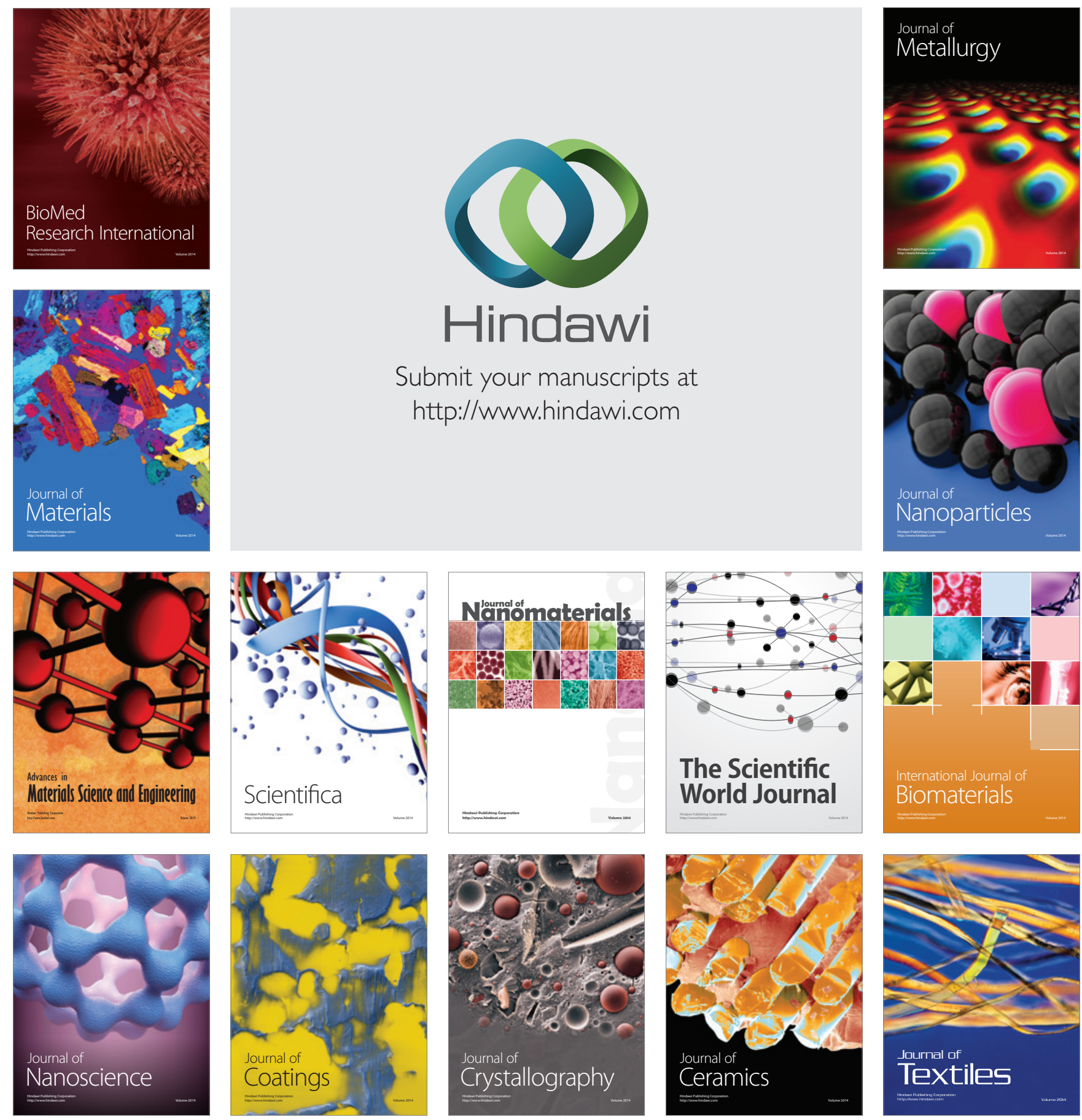